\title{
Sentinel surveillance of Chlamydia trachomatis infection in women terminating pregnancy
}

\author{
F E Skjeldestad, S A Nordbø, A Hadgu
}

\begin{abstract}
Aims: To evaluate demographic characteristics of women terminating their pregnancy for sentinel surveillance of Chlamydia trachomatis infection and to report changing prevalences of $C$ trachomatis over time within this study population.

Design: Screening for $C$ trachomatis in women seeking induced abortion was introduced in 1984 at the Department of Gynecology, Regional Hospital, Trondheim, Norway. Over the study years our department has used a precoded medical record covering sociodemographic, medically relevant data, also recording outcome of the $C$ trachomatis test. Throughout the study the Department of Microbiology applied cell culture, enzyme immunoassay, and, during the most recent years a nucleic acid test to identify $C$ trachomatis.

Statistical methods: Chi square test for linear trend and unconditional logistic regression.

Results: Over the study period, women having induced abortion were characterised by being most often single and more often at younger age. The overall age-adjusted prevalence of $C$ trachomatis declined from $9 \cdot 2 \%$ in 1985 to $3 \cdot 6 \%$ in 1995 , the major decline occurring from 1987 to 1991 , and affected all age-groups simultaneously. There was a $60 \%$ decrease in odds ratio of having a $C$ trachomatis infection from 1985 to 1991, and the crude and the adjusted odds ratios did not differ for any year examined.

Conclusion: Women deciding on pregnancy termination have demographic characteristics that identify high-risk groups for $C$ trachomatis infection. Despite these characteristics, which were relatively constant over the study period, the study population changed from being a high- to a low-prevalence population of $C$ trachomatis.

(Genitourin Med 1997;73:29-32)
\end{abstract}

Keywords: Surveillance; Chlamydia trachomatis; induced abortion

\section{Introduction}

There is no standardised surveillance system for Chlamydia trachomatis in Norway. For years laboratories have reported voluntarily to the National Institute of Public Health (NIPH) summary reports of the annual number of tests analysed and the number of testpositive specimens, while practitioners have provided weekly reports to NIPH on the number of new cases of $C$ trachomatis. ${ }^{1}$ An evaluation of these two reporting systems concluded that the laboratories reported annually on average $40 \%$ more incident cases of $C$ trachomatis from 1988 to 1994 than did practitioners. ${ }^{1}$

From 1982 onwards, several reports have found a significant association between postabortion endometritis/salpingitis and the occurrence of $C$ trachomatis at time of surgery. $^{2-4}$ In order to prevent sequelae of postabortal infections by initiating antibiotic treatment of test-positive women before the abortion is carried out, we recommended in 1984 that general practitioners in our catchment area begin screening for $C$ trachomatis in women demanding pregnancy termination. ${ }^{4}$

The aims of our study were to evaluate demographic characteristics of women terminating their pregnancy in relation to fulfilling the criteria as a target population for sentinel surveillance of $C$ trachomatis infections and to report changing prevalences of $C$ trachomatis over an 11-year period (1985-1995).

\section{Material and methods}

The Regional Hospital of Trondheim, Norway, has a catchment area that covers the county of Sør-Trøndelag (approximately 250000 inhabitants), among which 55000 women are of reproductive age. Over the years approximately $85 \%-90 \%$ of the therapeutic abortions in the county have been carried out at our department.

Cell culture was introduced as the laboratory test for $C$ trachomatis detection at our Department of Microbiology during the fall of $1982 .{ }^{5}$ Because of increasing screening activity in the county, the laboratory changed its detection method in 1985 to the less time-consuming and cheaper enzyme immunoassay (EIA) format (IDEIA $^{\mathrm{TM}}$ Chlamydia Test, Celltech Diagnostics, later named Novo BioLabs and DAKO). As soon as a blocking assay with monoclonal antibodies against $C$ trachomatis was commercially available, it was adopted as a confirmatory assay for all EIA positive specimens. In 1992, the IDEIA ${ }^{\mathrm{TM}}$ assay was replaced by a nucleic acid hybridisation test for the detection of ribosomal RNA (rRNA) of the target organism (PACE ${ }^{\mathrm{TM}} 2$, Gen-probe, San Diego, California). All reactive samples were retested with a blocking assay using unlabelled probes before they were released. Non-culture tests have been used on the majority of chlamydia specimens sent by mail since culture has been shown to have a low sensitivity when applied to this category of
Address correspondence to: Finn Egil Skjeldestad, Department of Gynecology and Obstetrics, University Hospital of Trondheim, 7006 Trondheim, Norway. 
Table 1 Study Population Characteristics

\begin{tabular}{|c|c|c|c|c|c|c|}
\hline & \multicolumn{6}{|c|}{ Year of event } \\
\hline & $\begin{array}{l}1985 \\
N=872\end{array}$ & $\begin{array}{l}1987 \\
N=791\end{array}$ & $\begin{array}{l}1989 \\
N=905\end{array}$ & $\begin{array}{l}1991 \\
N=808\end{array}$ & $\begin{array}{l}1993 \\
N=811\end{array}$ & $\begin{array}{l}1995 \\
N=756\end{array}$ \\
\hline $\begin{array}{c}\text { Age (years) } \\
13-14 \\
15-19 \\
20-24 \\
25-29 \\
30-34 \\
35-39 \\
40-50\end{array}$ & \begin{tabular}{r|}
$(\%)$ \\
\\
$19 \cdot 8$ \\
$29 \cdot 8$ \\
$21 \cdot 7$ \\
$13 \cdot 9$ \\
$10 \cdot 7$ \\
$4 \cdot 1$
\end{tabular} & $\begin{aligned}(\%) \\
0 \cdot 1 \\
19 \cdot 6 \\
32 \cdot 4 \\
17 \cdot 7 \\
13 \cdot 1 \\
10 \cdot 6 \\
6 \cdot 5\end{aligned}$ & \begin{tabular}{r|}
$(\%)$ \\
$18 \cdot 1$ \\
$31 \cdot 8$ \\
$23 \cdot 1$ \\
$11 \cdot 9$ \\
$10 \cdot 6$ \\
$4 \cdot 4$
\end{tabular} & $\begin{array}{r}(\%) \\
0 \cdot 1 \\
14 \cdot 4 \\
30 \cdot 8 \\
24 \cdot 4 \\
15 \cdot 0 \\
9 \cdot 8 \\
5 \cdot 6\end{array}$ & $\begin{array}{r}(\%) \\
15 \cdot 2 \\
30 \cdot 7 \\
23 \cdot 3 \\
16 \cdot 0 \\
10 \cdot 4 \\
4 \cdot 4\end{array}$ & $\begin{array}{r}(\%) \\
0 \cdot 1 \\
13 \cdot 5 \\
29 \cdot 2 \\
23 \cdot 1 \\
17 \cdot 2 \\
11 \cdot 6 \\
5 \cdot 2\end{array}$ \\
\hline $\begin{array}{l}\text { Marital status } \\
\text { Single } \\
\text { Cohabitants } \\
\text { Married } \\
\text { Information }\end{array}$ & $\begin{array}{l}51 \cdot 3 \\
18 \cdot 2 \\
28 \cdot 9\end{array}$ & $\begin{array}{l}63 \cdot 2 \\
11 \cdot 3 \\
24 \cdot 7\end{array}$ & $\begin{array}{l}57 \cdot 5 \\
18 \cdot 4 \\
23 \cdot 3\end{array}$ & $\begin{array}{l}55 \cdot 8 \\
21.7 \\
21.9\end{array}$ & $\begin{array}{l}62 \cdot 0 \\
17 \cdot 8 \\
20 \cdot 2\end{array}$ & $\begin{array}{l}56 \cdot 5 \\
26 \cdot 2 \\
17 \cdot 1\end{array}$ \\
\hline $\begin{array}{l}\text { Chlamydia test } \\
\text { Valid } \\
\text { Inconclusive } \\
\text { Information } \\
\text { not available }\end{array}$ & $\begin{array}{r}98 \cdot 3 \\
1.4 \\
0.3\end{array}$ & $\begin{array}{r}92 \cdot 3 \\
0.1\end{array}$ & $\begin{array}{r}94 \cdot 3 \\
0 \cdot 3\end{array}$ & $\begin{array}{r}97 \cdot 2 \\
0 \cdot 7\end{array}$ & $\begin{array}{r}94 \cdot 6 \\
0.4\end{array}$ & $\begin{array}{r}92 \cdot 3 \\
0 \cdot 7 \\
7 \cdot 1\end{array}$ \\
\hline
\end{tabular}

samples. ${ }^{6}$ However, culture was reintroduced in 1989 and has since then been used as a reference method for important patient groups and specimens with short transportation time. ${ }^{7}$

The hospital department of gynaecology has used a standardised precoded medical record for women having abortions since $1983 .{ }^{8}$ This record includes sociodemographic data, pregnancy histories and timing of event(s), information about the surgery, peroperative complications, and outcome of tests for $C$ trachomatis (table 1).

Specimen for $C$ trachomatis were collected most often at the preabortion consultation at the general practitioner's office. However, if no test result was available when the patient arrived at the hospital for surgery another specimen was collected at that time.

Statistical analyses were carried out by chi square test for linear trend and unconditional logistic regression in SAS. ${ }^{9}$ In the logistic regression analyses, the outcome of the chlamydia test was the dependent variable. We applied a change-in-estimate approach to adjust for confounding. ${ }^{10}$ Patients whose information for one of the variables listed in table 1 was incomplete were excluded from regression analyses. Age-standardised prevalences were estimated by the direct method using the age distribution of the total study population as reference. In all analyses we have chosen to present the data at two-year intervals starting 1985,1987 , etc, to 1995 .

Table 2 Prevalence of $\mathrm{C}$ trachomatis by Year of Event

\begin{tabular}{|c|c|c|c|c|c|c|}
\hline Valid cases & $\begin{array}{l}1985 \\
N=857\end{array}$ & $\begin{array}{l}1987 \\
N=730\end{array}$ & $\begin{array}{l}1989 \\
N=854\end{array}$ & $\begin{array}{l}1991 \\
N=785\end{array}$ & $\begin{array}{l}1993 \\
N=767\end{array}$ & $\begin{array}{l}1995 \\
N=698 x^{2}-t r .\end{array}$ \\
\hline $\begin{array}{c}\text { Age (years) } \\
13-14\end{array}$ & $(\%)$ & $(\%)$ & $(\%)$ & $(\%)$ & $(\%)$ & $(\%)$ \\
\hline $\begin{array}{l}15-19 \\
20-24 \\
25-29 \\
30-34 \\
35-50\end{array}$ & $\begin{array}{r}17 \cdot 0 \\
11.9 \\
7.5 \\
5.1 \\
1.5\end{array}$ & $\begin{array}{r}19 \cdot 6 \\
10 \cdot 4 \\
4 \cdot 5 \\
2 \cdot 1 \\
2 \cdot 4\end{array}$ & $\begin{array}{r}8 \cdot 2 \\
11 \cdot 2 \\
6 \cdot 2 \\
3 \cdot 1 \\
0 \cdot 8\end{array}$ & $\begin{array}{l}8.9 \\
5 \cdot 7 \\
3 \cdot 1 \\
0.9 \\
1.7\end{array}$ & $\begin{array}{l}9 \cdot 2 \\
6 \cdot 2 \\
2 \cdot 7 \\
1 \cdot 7 \\
0 \cdot 0\end{array}$ & $\begin{array}{l}6 \cdot 3 \ddagger \\
5 \cdot 2 \ddagger \\
3 \cdot 6 \ddagger \\
0 \cdot 9 \ddagger \\
0 \cdot 0^{\star}\end{array}$ \\
\hline $\begin{array}{l}\text { Crude rate } \\
\text { Age-adjusted rate }\end{array}$ & $\begin{array}{l}9 \cdot 5 \\
9 \cdot 2\end{array}$ & $\begin{array}{l}8 \cdot 6 \\
8 \cdot 2\end{array}$ & $\begin{array}{l}7 \cdot 0 \\
6 \cdot 8\end{array}$ & $\begin{array}{l}4 \cdot 2 \\
4 \cdot 3\end{array}$ & $\begin{array}{l}4 \cdot 3 \\
4 \cdot 3\end{array}$ & $\begin{array}{l}3.4 \ddagger \\
3 \cdot 6 \ddagger\end{array}$ \\
\hline
\end{tabular}

\section{Results}

The number of induced abortions varied over the study period from 872 in 1985 to 905 in 1989 and 756 in 1995 (table 1). The largest number of pregnancy terminations was found among women aged 20-24 years and the lowest number was found among women 40 years orø older throughout the entire study period. Byö age, the proportion of women less than $20 \cong$ years old decreased, while the proportion of women aged 25-29 and of those aged 30-34 years increased over the study period (table 1$).$ By marital status there was a shift towards aos larger proportion of unmarried cohabitingo women having a pregnancy terminated at the $\frac{\overline{\bar{N}}}{\bar{N}}$ end of the study period, during which period a $40 \%$ reduction in the proportion of married $\stackrel{\mathbb{}}{\circ}$ women seeking abortion was observed. Thew proportion of single women actually having an $\vec{\circ}$ abortion did not change significantly during $\vec{\omega}$ the study years (table 1 ).

Over the study period a declining trend of $\stackrel{5}{=}$ valid chlamydia tests was observed, varying $\omega$ from $98.3 \%$ valid tests in 1985 to $92.3 \%$ in1995 (table 1). The majority of women $(88 \%$, त्c $222 / 252$ ) with an invalid test had no specimen윽 collected. Missing information for validchlamydia tests varied by the age of the ${ }_{\mathbb{D}}^{T}$ patients. Among women $\leqslant 29$ years of age, approximately $4 \%$ had an invalid test for $C$ trachomatis or no test was collected; among women $\geqslant 30$ years of age, about $7 \%$ of thee women lacked a valid answer. The number of missing data varied consistently with ageo throughout the entire study period.

Except for 1989, the prevalence of $C$ trachomatis was highest among teenagers andoे decreased significantly by increasing age. The crude overall prevalence of $C$ trachomatis was윽 not different from the age-adjusted prevalence and declined from $9.5 \%$ in 1985 to $3.4 \%$ ino 1995 (table 2). Significant decreasing trendson were observed in all age-groups. Quantitatively the decrease was larger in the younger age-groups; however, the proportionatelyo largest reduction was found in women $30-34$ years of age ( $82 \%$ ) (table 2 ). This occurred ato the same time that the proportionate numbers of women 30-34 years of age increased (table 1).

We performed multivariate analyses ton adjust for the effects over time on the occur- -5 rence of $C$ trachomatis infection of the chang-o ing characteristics of the study population. Weo examined $C$ trachomatis infection by "year of event" as the main exposure, 1985 serving as" the reference year. The model that gave the best fit included age and marital status, whilem parity, previous spontaneous and previous induced abortions were insignificant predic- $\frac{0}{0}$ tors. Marital status was categorised as shown in table 1 , while age was recoded into fouro subgroups: $\leqslant 19$ years; $20-24$ years; $25-29 \leqq$ years; and $\geqslant 30$ years. Overall, the adjusted odds ratio of being infected with $C$ trachomatis decreased by more than $60 \%$ from 1985 to 1991. However, since 1991 there have been only minor changes in the adjusted odds ratio for being $C$ trachomatis infected. For any year, the crude odds ratio for having a $C$ trachomatis 
Table 3 Odds ratios of chlamydial infection

\begin{tabular}{|c|c|c|c|c|c|}
\hline & $\begin{array}{l}n \\
\operatorname{chl}(+)\end{array}$ & $\begin{array}{l}N \\
\text { tested }\end{array}$ & $\begin{array}{l}\text { Crude } \\
\text { odds ratio }\end{array}$ & $\begin{array}{l}\text { Adjusted } \\
\text { odds ratio }\end{array}$ & $\begin{array}{l}95 \% \text { confidence } \\
\text { interval }\end{array}$ \\
\hline $\begin{array}{l}\text { Year } \\
1985 \\
1987 \\
1989 \\
1991 \\
1993 \\
1995\end{array}$ & $\begin{array}{l}80 \\
63 \\
60 \\
33 \\
33 \\
24\end{array}$ & $\begin{array}{l}843 \\
726 \\
848 \\
780 \\
767 \\
696\end{array}$ & $\begin{array}{l}1 \cdot 0 \\
0.9 \\
0.7 \\
0.4 \\
0.4 \\
0.3\end{array}$ & $\begin{array}{l}1 \cdot 0 \\
0.9 \\
0 \cdot 7 \\
0.4 \\
0.4 \\
0.3\end{array}$ & $\begin{array}{l}\text { (ref) } \\
(0.5-1.4) \\
(0.5-1.0) \\
(0.2-0.7) \\
(0.3-0.5) \\
(0.2-0.5)\end{array}$ \\
\hline $\begin{array}{c}\text { Age (years) } \\
\leqslant 19 \\
20-24 \\
25-29 \\
\geqslant 30\end{array}$ & $\begin{array}{r}97 \\
125 \\
48 \\
23\end{array}$ & $\begin{array}{l}799 \\
1442 \\
1051 \\
1368\end{array}$ & $\begin{array}{l}8 \cdot 1 \\
5 \cdot 6 \\
2 \cdot 8 \\
1 \cdot 0\end{array}$ & $\begin{array}{l}4 \cdot 5 \\
3 \cdot 5 \\
2 \cdot 1 \\
1 \cdot 0\end{array}$ & $\begin{array}{l}(2 \cdot 7-7 \cdot 4) \\
(2 \cdot 2-5 \cdot 8) \\
(1 \cdot 3-3 \cdot 6)\end{array}$ \\
\hline $\begin{array}{l}\text { Marital status } \\
\text { Single } \\
\text { Cohabitants } \\
\text { Married }\end{array}$ & $\begin{array}{r}228 \\
51 \\
14\end{array}$ & $\begin{array}{r}2722 \\
893 \\
1045\end{array}$ & $\begin{array}{l}6 \cdot 7 \\
4 \cdot 5 \\
1 \cdot 0\end{array}$ & $\begin{array}{l}3 \cdot 6 \\
2 \cdot 9 \\
1 \cdot 0\end{array}$ & $\begin{array}{l}(2 \cdot 0-6 \cdot 4) \\
(1 \cdot 5-5 \cdot 4)\end{array}$ \\
\hline Included in ana & & 4660 & & & \\
\hline
\end{tabular}

The variables in the table are adjusted for one another. Parity, no. of previous induced abortions, no. of previous ectopic pregnancies, no. of previous spontaneous abortions did not enter the model. infection did not differ from the adjusted odds ratio (table 3 ). Single and cohabiting women were at significantly higher risk of acquiring $C$ trachomatis compared with married women. Over the entire study period, the adjusted odds ratio of $C$ trachomatis infection was inversely correlated to age (table 3). No interaction was detected between year of event and age or between year of event and marital status.

\section{Discussion}

From 1985 to 1991 the overall age-adjusted prevalence of $C$ trachomatis decreased by more than $60 \%$ in women terminating their pregnancy in the county of Sør-Trøndelag (table 2). Most of the decrease in prevalence of $C$ trachomatis occurred from 1987 to 1989 in teenagers and from 1989 to 1991 in the other age-groups.

During the first years of testing, we detected $C$ trachomatis from the pool of infected women. From introduction of $C$ trachomatis analyses at the Department of Microbiology in 1982, the test activity within the county increased from 2200 tests in the initial year to nearly 14000 in 1985 and over 30000 in $1989 .^{7}$ Assuming that each woman had only one test for $C$ trachomatis, the annual number of tests from 1989 to 1995 in our county would imply that at least $50 \%$ of all sexually active women 15-44 years old were screened yearly. The majority of the tests were collected from women who had routine gynaecological examinations in general practice during contraceptive counselling, or at visits for papsmear or for antenatal care. We do not know how many of our study participants have had repeated tests for $C$ trachomatis during visits at a general practitioner's office or other medical settings prior to their most recent abortion. However, the high level of $C \mathrm{tra}$ chomatis screening activity in the hospital's catchment area and the effective treatment of index persons and their partners reduced the duration of infection among the prevalent cases in the general population. Therefore, our data set may reflect a change from prevalence to incidence data over the study period.
Several women had more than one induced abortion throughout the study period. Therefore, the observations in our data set were not completely independent of each other since several women $(\sim 20 \%$ within time frame of study) had been tested for $C$ trachomatis at a previous induced abortion. When we restricted the analyses to women who had their first induced abortion only, results similar to those in the overall analyses were found: a nearly $60 \%$ decrease in adjusted odds ratio of being $C$ trachomatis infected during the years 1987 through 1991 .

Hillis et al have demonstrated that the decline in incident cases in persons who have had a negative test within the preceding 12 months was proportional to the decline in the overall prevalence observed in clients in family planning clinics, STD clinics, and in private providers' offices from 1987 to 1991 in Wisconsin, USA. ${ }^{11}$ Both the study from Wisconsin and ours from Norway report decreasing prevalences evenly distributed among segments of women who have previously been tested for $C$ trachomatis.

The Department of Microbiology at our hospital used mainly three tests during the time of the study. Over the study years there are only minor variations in the number of positive tests by type of test applied. ${ }^{7}$ However, culture, EIA and GenProbe have different test performances. We do not know how changing sensitivity and specificity of culture, EIA or GenProbe have effected our results. Neither were we able to analyse test specific prevalences since we did not register individual data by test applied. However, it is possible that some of the decline in the observed prevalence is attributable to changes in type of diagnostic tests used of the study period (varying sensitivity and specificity). From Sweden laboratory data for $C$ trachomatis were analysed over time (1985-93); however, the authors claimed that detection method did not contribute to predicting changing prevalences of $C$ trachomatis infection. ${ }^{12}$ Similar findings are reported in trend analyses of $C$ trachomatis infection by detection methods from the US. ${ }^{11}$

The changing frequency of mixing partners and the changing pattern of contraception, particularly condom use, are important behavioural characteristics in understanding changing prevalences of STDs over time. Large HIV/AIDS campaigns in Norway, starting in 1985, have focused on risky behaviour and have emphasised condom use as the best STD prevention. However, there is little evidence that these campaigns have changed sexual behaviour and condom use among the heterosexual population. ${ }^{13-15}$ Thus, we find it unlikely that minor changes in frequency of partner mixing and slightly improved condom use over the time period might explain the observed declining trends of $C$ trachomatis.

In many countries, routine testing for $C$ trachomatis infections started before any national guidelines were developed or even before $C$ trachomatis infection was included in the national STD legislation. In Sweden, $C$ tra- 
chomatis was legally designated as a venereal disease agent in April 1988. ${ }^{12}$ In Norway, $C$ trachomatis was incorporated into the Communicable Diseases Control Act on January 1, 1995. ${ }^{16}$ In Sweden, the sharpest decrease in prevalence of $C$ trachomatis infections occurred before $C$ trachomatis control was incorporated into the legal code, ${ }^{12}$ while in Norway this has happened without any legislation changing the status of index persons infected with $C$ trachomatis.

In countries or regions where liberal testing for genital $C$ trachomatis infection has been done, decreasing trends for $C$ trachomatis infections have been observed since the middle of the 1980s. Moreover, declining trends of $C$ trachomatis infections have been reported from antenatal clinics, ${ }^{12}{ }^{17}$ from family planning clinics, ${ }^{11}{ }^{12}{ }^{18-20}$ from primary health clinics, ${ }^{12-21}$ and from youth clinics. ${ }^{12}$ Our findings are similar to the findings of studies on trends of $C \mathrm{tra}$ chomatis infections in women deciding on pregnancy termination in Oslo, Norway ${ }^{22}$ and in Sweden from 1984 to $1991 . .^{23}$ However, there are few data to support that morbidity and sequelae from $C$ trachomatis infections have changed, even among abortion patients. No one has studied whether massive screening for $C$ trachomatis infections in abortion patients has reduced morbidity associated with surgically performed abortion. We recommend such studies.

Ideally, a population of sexually active individuals who are characterised by infrequent use of contraception and who are not living in a stable relationship would be the best population for sentinel surveillance of $C$ trachomatis infections. This study confirms that women deciding on pregnancy termination have characteristics that identify high-risk groups for $C$ trachomatis infections ${ }^{11}{ }^{12} 23$; they are most often at young age and most often single. Therefore, it is feasible to carry out $C$ trachomatis infection surveillance among women terminating their pregnancies. ${ }^{24}$ Despite this risk profile, women having had pregnancy termination between 1985 and 1995 changed from a highto a low-prevalence population of $C$ trachomatis.

The study has been supported by grant from the Norwegian Council for Research.
1 Aavitsland P, Nilsen $\emptyset$. Seksuelt overførte sykdommer (SOS) 1994. MSIS-rapport 1995;23:5 (Sexually transmitted diseases (STD) 1994) (In Norwegian).

2 Møller B, Ahrons S, Laurin J, Mårdh P-A. Pelvic infection after elective abortion associated with Chlamydia tra chomatis. Obset and Gynecol 1982;59:210-3.

3 Quigstad E, Skaug K, Jerve F, Vik ISS, Ulstrup JC. Therapeutic abortion and Chlamydia trachomatis infection. Br ₹ Venereal Dis 1982;38:182-3.

4 Skjeldestad FE, Tuveng J, Solberg AG, Molne K, Dalen A, Buhaug $\mathrm{H}$. Induced abortion: Chlamydia trachomatis and postabortal complications. A cost benefit analyses. Acta Obstet Gynecol Scand 1988;67:525-9.

5 Ripa KT, Mårdh P-A. Cultivation of Chlamydia trachomatis in cycloheximide-treated McCoy cells. $\mathcal{F}$ Clin Microbiol 1977;6:328-31.

6 Nordbø SA, Mehl A, Vik IS Samdal, Ragnhildstveit E. Diagnosis of chlamydial infections: culture or enzyme immunoassay (EIA)? Tidsskr Nor Lagefor 1991;111: 2413-6 In Norian

7 Annual reports. Department of Microbiology, University Hospital of Trondheim, Norway. Trondheim 1986 to 1996.

8 Skjeldestad FE. Using induced abortion to measure contra- $\mathbb{Q}$ ceptive efficacy. Fam Plann Perspect 1995;27:71-3,96.

9 SAS Institute. SAS/STAT software: The GENMOD pro-cedure, Release 6.09. Cary, NC: SAS Technical Report P-243, 1993.

10 Maldonado G, Greenland S. Simulation study of confounder-selection strategies. Am $\mathcal{F}$ Epidemiol 1993;1389: $\bar{\omega}$ 23-36.

11 Hillis SD, Nakashima A, Amsterdam L, Pfister J, Vaughnce $M$, Addiss $D$. The impact of a comprehensive chlamydia prevention program in Wisconsin. Fam Plann Perspect $\omega$ 1995;27:108-11.

12 Herrmann B, Egger $M$. Genital chlamydial infections in Uppsala county, Sweden, 1985-1993: Declining rates for how much longer? Sex Transm Dis 1995;22:253-60.

13 Bakketeig LS, Hareide B. Rapport fra seksualvaneundersøkelsene I 1987 og 1992. Oslo: Folkehelsa, 1993(Report of the Surveys of Sexual Habits in Norway, 1987 T (Report of the Surveys of Sex

14 Noack T, Østby L. Mer effektiv prevensjonsbruk. Samfunsspeilet 1991;5:20-4 (More effective use of contraception) (In Norwegian)

15 Skjeldestad FE. Choice of contraceptive modality by women in Norway. Acta Obstet Gynecol Scand 1994;73:G 48-52.

16 Communicable Disease Control Act. Norwegian Board of Health. Oslo. IK-2522, 1995.

17 Thejls H, Gnarpe J, Gnarpe H, Larsson G. Age-related decrease in prevalence of Chlamydia trachomatis among pregnant women. Sex Transm Dis 1991;18:137.

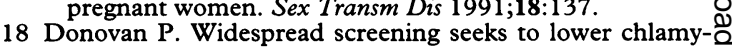
dia prevalence. Fam Plann Perspect 1992;24:135-6.

19 Addiss DG, Vaughn ML, Ludka D, Pfister J, Davis JP. Decreased prevalence of Chlamydia trachomatis infection associated with a selective screening program in family planning clinics in Wisconsin. Sex Transm Dis 1993;20: 28-35.

20 Chlamydia prevalence and screening practices-San Diego county, California, 1993. MMWR 1994;43:366-9,375.

21 Halvorsen LE, Skjeldestad FE, Nordbø SA, Løge I. Which women should be screened for Chlamydia trachomatis attending general practice need chlamydial screening? Tidsskr Nor Lagefor 1992;112:2080-1 (In Norwegian, English summary).

22 Baldvinsdottir G, Størvold G, Melby K. Prevalence of Chlamydia trachomatis in women requesting abortion in Oslo, 1985-91. Tidsskr Nor Lagefor 1993;113:818-20 (In工

23 Ripa T. Epidemiologic control of genital Chlamydia tra-을 chomatis infections. Scand F Infect Dis 1990;69:157-67 (suppl.).

24 Aavitsland P, Lystad A. Recommendations on indications for laboratory testing for genital Chlamydia trachomatis $N$ infection in adults. Tidsskr Nor Lagefor 1995;115:3141-4N (In Norwegian, English summary). 